\title{
Archaeological Survey of the Covel Gardens Landfill Area in San Antonio, Bexar County, Texas
}

Daniel R. Potter

Center for Archaeological Research

Follow this and additional works at: https://scholarworks.sfasu.edu/ita

Part of the American Material Culture Commons, Archaeological Anthropology Commons, Environmental Studies Commons, Other American Studies Commons, Other Arts and Humanities Commons, Other History of Art, Architecture, and Archaeology Commons, and the United States History Commons

Tell us how this article helped you.

This Article is brought to you for free and open access by the Center for Regional Heritage Research at SFA ScholarWorks. It has been accepted for inclusion in Index of Texas Archaeology: Open Access Gray Literature from the Lone Star State by an authorized editor of SFA ScholarWorks. For more information, please contact cdsscholarworks@sfasu.edu. 


\section{Archaeological Survey of the Covel Gardens Landfill Area in San Antonio, Bexar County, Texas}

\section{Creative Commons License}

\section{(c) (1) (8)}

This work is licensed under a Creative Commons Attribution-NonCommercial 4.0 International License 


\title{
ARCHAEOLOGICAL SURVEY OF THE COVEL GARDENS LANDFILL AREA IN SAN ANTONIO, BEXAR COUNTY, TEXAS
}

\author{
Daniel R. Potter
}

Center for Archaeological Research

The University of Texas at San Antonio(i

Archaeological Survey Report, No. 202

1990 
A list of publications by the Center for Archaeological Research can be obtained by sending $\$ 1.00$ to the Center for Archaeological Research, The University of Texas at San Antonio, San Antonio, Texas 782850658. 


\begin{abstract}
In March 1990, archaeologists from the Center for Archaeological Research, The University of Texas at San Antonio, conducted a surface survey and subsurface testing at a locality proposed for a landfill by Waste Management of North America, Inc. Survey and testing activities were performed in order to locate and evaluate any archaeological remains which might be affected by landfill construction and operation. In addition, a private collection of artifacts originating from the project area was documented. Prehistoric archaeological remains were encountered in the western portion of the study area, and a new site number was designated for these remains, $41 \mathrm{BX} 873$. Because of prior disturbance to this site, we recommend that no further investigation is needed.
\end{abstract}




\section{TABLE OF CONTENTS}

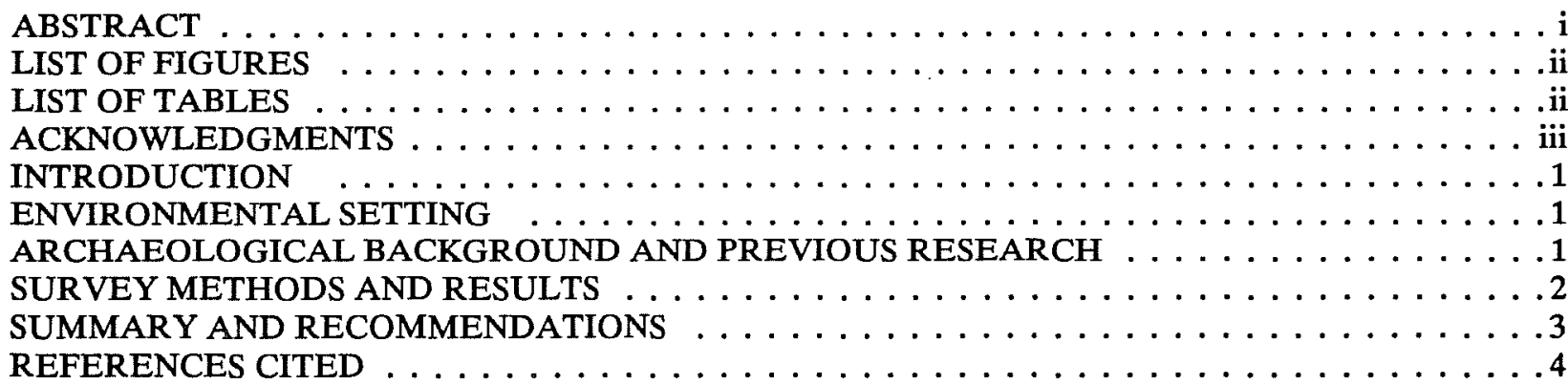

\section{LIST OF FIGURES}

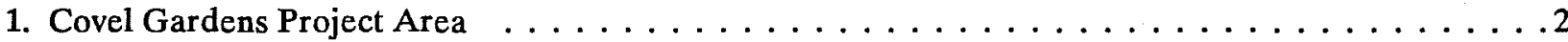

\section{LIST OF TABLES}

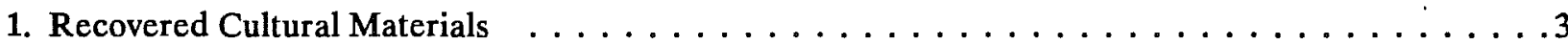




\section{ACKNOWLEDGMENTS}

The author wishes to thank Mr. James M. Norstrom, P.E., project manager for Waste Management of North America, Inc., for his assistance in completing this project. It should be noted here that there were no legal requirements for Waste Management of North America, Inc., to undertake this project. The company's concern for local historical and archaeological resources is greatly appreciated. My wife Maureen Brown assisted in field work, laboratory, and recording activities for this project. Mr. Andrew Clark, former owner of the project property, kindly loaned his collection of artifacts from site $41 \mathrm{BX} 873$ for analysis and recording, and provided information concerning past disturbance in the site area. Jack D. Eaton, acting director of the Center for Archaeological Research, supervised this project. The office staff at the Center for Archaeological Research were instrumental in the preparation of this report. 



\section{INTRODUCTION}

In January 1990, Mr. Jim Norstrom of Waste Management of North America, Inc., requested that archaeological investigations be carried out by the Center for Archaeological Research (CAR), The University of Texas at San Antonio (UTSA), in order to evaluate and report any archaeological resources which might be affected by the development of a landfill facility. At that time no sites were recorded for the area, but the proposed landfill was thought to be located within a high probability area for archaeological resources (Denton 1985; Eaton 1990).

Three days of field work were accomplished in March 1990. Field work included a complete surface examination and shovel tests. Daniel Potter served as coprincipal investigator and project director, and Jack D. Eaton, acting director of the CAR, was principal investigator. The work crew consisted of two archaeologists. All recovered materials, field notes, photographs, and other information related to this project are curated at the CAR-UTSA.

\section{ENVIRONMENTAL SETTING}

The project area occupies an east-facing section of a low ridge between Medio Creek and the Medina River, just south of the Medina Base Military Reservation in San Antonio, Texas (Fig. 1). Access to the area was gained from Covel Road, which forms the eastern boundary of the project area. The eastern edge of the study area is located on an eroded second terrace (T2) of Medio Creek. From this boundary, the area slopes upwards to the west, where it is bounded by the existing Standard Industries property.

Soils in the project area are of the Lewisville-Houston, Black terrace association (HuB, HsB, HuC, HtA; Taylor, Hailey, and Richmond 1966). These consist of deep, clayey dark gray to black soils (Munsell reading on dry soil core is 10YR 2/1; Munsell Color 1975) with varying degrees of slope and gravel content. Gravel content increases on ridge tops and slopes. Taylor, Hailey, and Richmond (1966:20-21) report that gravel content in higher slope contexts can reach up to $60 \%$ in volume. Within the project area, much of this gravel is composed of small flint nodules. It is likely that this feature is one reason for prehistoric settlement in the area, as flint (also termed "chert") was an important raw material for prehistoric stone tool manufacture. Mr. Andrew Clark, previous owner of the property, reports that considerable disturbance of the area soils had occurred through plowing, mechanical scraping, burning, and importation of up to four inches of topsoil at various localities. The disturbances are predominantly in the higher elevations in the western third of the project area. All of this has served to disturb both the natural soil characteristics and the archaeological record in parts of the area.

\section{ARCHAEOLOGICAL BACKGROUND AND PREVIOUS RESEARCH}

Inspection of records on file at the Texas Archeological Research Laboratory in Austin, Texas, reveals that no sites have been recorded within or near the project area. No systematic archaeological research has been conducted in this project area or adjacent to it. At present, the closest recorded site to the area (on the Macdona 7.5' USGS map) is $41 \mathrm{BX} 344$, an important prehistoric site located some $6 \mathrm{~km}$ to the south (McGraw and Hindes 1987).

The project site is not far removed from a portion of the Medina River drainage which has been studied in detail (McGraw and Hindes 1987). This same area, proposed for a surface water reservoir, is currently being further studied by archaeologists from SMU and Texas A\&M University. The initial survey and testing of many sites within the southwestern Bexar County area are discussed in the report by McGraw and Hindes (1987). Along the Medina River and its tributary streams (including Medio Creek), prehistoric sites were found to be correlated with ancient confluences, or junctures of streams. Cultural materials were found in these locations at depths of up to $3 \mathrm{~m}$ below the modern surface, and there is a high probability that other deeply buried remains exist within the area on older stream terraces, as McGraw and Hindes (1987:361) suggest. In addition to frequently being deeply buried, prehistoric sites in this area are relatively large, containing scatters of burned limestone and chert debitage (McGraw and Hindes 1987).

The reservoir survey has also revealed a long history of occupation in the general area of the Covel Gardens landfill site. McGraw and Hindes (1987:363-367) report evidence of occupation dating from Late Paleo-Indian times (8000-5000 B.C.; Black and McGraw 1985:322) through the Historic period within the greater Medina River drainage area. 
This page has been

redacted because it

contains restricted

information. 
TABLE 1. RECOVERED CULTURAL MATERIALS

\begin{tabular}{|c|c|c|c|c|c|c|c|c|c|c|}
\hline \multirow[b]{2}{*}{ Provenience } & \multirow[b]{2}{*}{ Depth (cm) } & \multirow[b]{2}{*}{$\begin{array}{c}\text { Projectile } \\
\text { Point }\end{array}$} & \multirow[b]{2}{*}{ Biface } & \multicolumn{5}{|c|}{ CHERT DEBITAGE } & \multirow[b]{2}{*}{ Cores } & \multirow[b]{2}{*}{ TOTAL } \\
\hline & & & & Primary & Secondary & Teritary & Chips & Fire-Spalled & & \\
\hline $\begin{array}{l}\text { ST 1 } \\
\text { ST 2 } \\
\text { ST 3 } \\
\text { ST 4 } \\
\text { ST 5-1 } \\
\text { ST 5-2 } \\
\text { ST 5-3 } \\
\text { Surface }\end{array}$ & $\begin{array}{r}65 \\
55 \\
30 \\
55 \\
00-15 \\
15-30 \\
30-45\end{array}$ & 1 & 1 & 1 & $\begin{array}{l}1 \\
1 \\
1\end{array}$ & 2 & $\begin{array}{c}1 \\
1 \\
13 \\
3 \\
1 \\
2\end{array}$ & $\begin{array}{c}1 \\
20 \\
7\end{array}$ & 2 & $\begin{array}{c}1 \\
2 \\
4 \\
36 \\
10 \\
1 \\
3 \\
4\end{array}$ \\
\hline TOTAL & & 1 & 2 & 1 & 3 & 2 & 21 & 28 & 3 & 61 \\
\hline
\end{tabular}

site was likely a "quarry," or chert procurement and reduction locus, for prehistoric populations in the Medina River/Medio River drainage area. The two cores recovered (Table 1) are additional support for this interpretation. As a result of this evidence, it was decided to designate most of the higher elevation area at the western margin of the project area as an archaeological site, $41 \mathrm{BX} 873$. The site number was issued by and recorded at the Texas Archeological Research Laboratory, Balcones Research Center, The University of Texas at Austin.

Shovel tests were also used to evaluate site 41 BX 873 and its surrounding area. ST 3, ST 4, and ST 5 were located within the site boundaries, while ST 1 and ST 2 sampled an extremely low-density scatter near Covel Road. These tests did not produce significant results. While ST 1, ST 2 , and ST 3 produced a total of only seven chert items (see Table 1), ST 4 and ST 5 produced 50 pieces of debitage, or about $82 \%$ of all cultural materials collected in the project area. ST 4 and ST 5 are therefore thought to be located in the area of most intensive prehistoric usage.

Discussion with the previous owner of the property, Mr. Andrew Clark revealed that he knew of the existence of the archaeological site, and had made a small collection of artifacts from an area matching the location of ST 4 and ST 5. The entire site had been very thoroughly disturbed previous to the purchase of the land by Waste Management of North America, Inc. Mr. Clark reported that the site had been mechanically cleared of trees and brush, completely burned, and additional fill had been deposited there at various times in the past. The Clark collection from 41 BX 873 was recorded and photographed at the CAR-UTSA laboratory and returned to the owner. The collection, comprising 28 artifacts, included points of the Pedernales, Gower/Hoxie/Uvalde, Darl(?), and Kinney(?) types, as well as unclassified biface fragments and flakes. The point types indicate that prehistoric occupation of $41 \mathrm{BX} 873$ dates at least as early as the Early Archaic or "Pre-Archaic" period (Sollberger and Hester 1972; Black and McGraw 1985), beginning ca. 5000 B.C.

\section{SUMMARY AND RECOMMENDATIONS}

While archaeological materials are rare within the project area, enough material remains to indicate that the western margin of the proposed landfill had been used from Early Archaic times onward as a lithic procurement and reduction locus, or "quarry." The area in which these activities took place has been designated as an archaeological site, $41 \mathrm{BX} 873$. However, the very thin distribution of cultural materials and the apparent disturbance of the site by power machinery, burning, erosion, and importation of fill, largely nullifies the value of this site for future research and conservation purposes. The site is not considered potentially eligible for nomination to the National Register of Historic Places or as a State Archeological Landmark. For this reason, no further archaeological research is recommended for the project area. However, North American Waste Management, Inc., may wish to consider on-site monitoring of $41 \mathrm{BX} 873$ if and when heavy earth-moving or other intensive development of the site area is to occur. 


\section{REFERENCES CITED}

Black, S. L. and A. J. McGraw

1985 The Panther Springs Creek Site: Cultural Change and Continuity within the Upper Salado Creek Watershed, South-Central Texas. Center for Archaeological Research, The University of Texas at San Antonio, Archaeological Survey Report 100.

Denton, M. H.

1985 Letter to Mr. Michael R. Keil, May 13.

Eaton, J. D.

1990 Letter to Mr. James Norstrom, January 26.

McGraw, A. J. and K. Hindes

1987 Chipped Stone and Adobe: A Cultural Resources Assessment of the Proposed Applewhite Reservoir, Bexar County, Texas. Center for Archaeological Research, The University of Texas at San Antonio, Archaeological Survey Report 163.

Munsell Color

1975 Munsell Soil Color Charts. Kollmorgen Corporation, Baltimore, Maryland.

Sollberger, J. B. and T. R. Hester

1972 The Strohacker Site: A Review of PreArchaic Manifestations in Texas. Plains Anthropologist 17(58):326-344.

Taylor, F. B., R. B. Hailey, and D. L. Richmond 1966 Soil Survey of Bexar County, Texas. United States Department of Agriculture, Soil Conservation Service, in cooperation with Texas Agricultural Experiment Station, Series 1962(12). 